\title{
Naturens Kemi - processer og påvirkninger
}

Af geolog Per S Sundberg

Udgangspunkteti “Naturens kemi” er naturen set under en naturvidenskabelig synsvinkel og med hovedvægten lagt på kemi. Bogen omfatter mange forskellige fagområder og er primært beregnet til undervisningsbrug.

\section{Bogens opdeling}

Bogen er opdelt i fem hovedkapitler, hvoraf de tre første behandler de miljøkemiske forhold i luft, vand og jord. De to sidste kapitler giver henholdsvis et bud på det globale kredsløb samt koblingen mellem forskellige miljøproblemer og de redskaber der bruges til at vurdere dem.

\section{Geologiske øjne...}

..falder naturligt på kapitlet om lithosfæren. Det er det største kapitel på hele 137 sider.
På helt klassisk vis starter afsnittet med en oprulning af lithosfærens opbygning, samt byggestenene i de overfladenære jordlag (primære og sekundære mineraler, organisk stof) afsluttende med de jordbundsdannende processer. Knapt så klassisk men meget interessant er afsnittet om forurenende stoffer i jord- og grundvand. Her gennemgås forskellige næringsstoffer fra handels- og husdyrgødning samt, hvad der er nok så aktuelt, stoffer fra punkt-forureninger, pesticider og detergenter. Kapitlet fortsætter med "Jordbundens filterfunktion”, dvs. jordbundens evne til at rense det vand, der går i grundvandsmagasiner eller til søer og vandløb. Filtreringsprocessen består af en lang række kemiske processer. Til sidst $i$ kapitlet behandles meget logisk grundvandet med de (kemiske) processer, der gør sig gældende under vandets strømning til og i magasinerne.

\section{Lærebog}

Lad det være sagt med det samme, så er det ikke en bog i den lette ende. Det er udpræget en bog til under-visningsbrug på lidt højere niveau, og indeholder som sådan også, hvad der skal være af "kedelige” formler, grafer og kemiske strukturer. Den flotte farveforside af en stæreflok over Haasberg Sø står noget i kontrast til den udprægede sparsommelighed, der er udvist med hensyn til at benytte farver $\mathrm{i}$ illustrationerne inde $\mathrm{i}$ bo-gen. En formildende omstændighed er, at man i en lang række bokse relaterer eller supplerer det mere teo-retiske stof til håndgribelige eksempler. Faktisk er det ret underholdende bare at springe fra boks til boks og blive fodret med små, afgrænsede informationer og eksempler.

Bogen er (vel)skrevet af en rckke forskere og derefter redigeret til en samlet fremstilling af Marianne Berthelsen og Jes Fenger. Gyldendals forlag. Bogen er på 368 sider og koster indbundet $k r$. 549, ISBN: 87-02-03034-9. 